\title{
TUGAS PEMODELAN PROSES BISNIS
}

\section{PENGENALAN PROSES BISNIS}

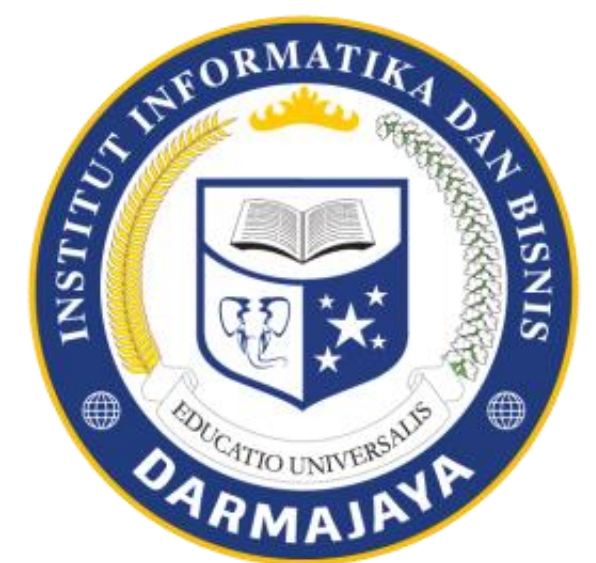

Disusun oleh :

ARIFQI ARYUNAS (1711050011)

3SI-P2

\section{INSTITUT INFORMATIKA DAN BISNIS}

DARMAJAYA

SEMESTER GANJIL T.A 2018/2019 


\begin{abstract}
Kompetensi Pengenalan Proses Bisnis Mampu menjelaskan Proses bisnis Mampu memberikan contoh sebuah proses bisnis.

\section{Bagian Isi}

Pengertian Analisa Proses Bisnis Analisa proses bisnis adalah kajian dan evaluasi yang dilakukan terhadap kegiatankegiatan proses bisnis Perusahaan untuk mengidentifikasikan dampak dari kegiatan tersebut dalam menciptakan nilai atau menambah nilai terhadap bisnis Perusahaan. Analisa proses bisnis merupakan salah satu kegiatan yang harus dilakukan perusahaan pada saat perusahaan akan melakukan rekayasa proses bisnis. Untuk lebih menjelaskan hubungan antara analisa proses bisnis dengan rekayasa ulang proses bisnis, terlebih dahulu kita lihat tahapan-tahapan yang harus dilakukan dalam rangka melakukan rekayasa ulang proses bisnis.
\end{abstract}

Menurut Whitten (2001, p21), dalam melakukan rekayasa ulang proses bisnis ada 3 tahap besar yaitu:

1. Identifikasi Value Chain Pada tahap ini dilakukan identifikasi kegiatan-kegiatan pada setiap fungsi perusahaan yang harus dilakukan oleh perusahaan dalam menjalankan proses bisnisnya. Kegiatankegiatan ini merupakan rangkaian kegiatan yang secara bersama akan membentuk suatu kombinasi proses yang dapat memberikan nilai tambah bagi proses bisnis perusahaan. Besar kecilnya nilai tambah yang diberikan oleh suatu kegiatan pada proses bisnis Perusahaan sangatlah bersifat spesifik untuk perusahaan tertentu dan untuk industri tertentu yang sangat tergantung faktor internal perusahaan antara lain strategi bisnis, sumberdaya dan fasilitas produksi yang dimiliki dan visi dari pemimpinnya, serta faktor eksternal antara lain kondisi kompetisi, kondisi industri, peraturan pemerintah, dan faktor sosio ekonominya.

2. Tahap Analisa Setiap Kegiatan Dalam Proses Bisnis Analisa terhadap setiap kegiatan dalam proses bisnis perusahaan dari segi waktu, bottlenecks, biaya untuk mengidentifikasikan dampak setiap kegiatan dalam menciptakan atau menambah nilai bisnis Perusahaan. Dalam tahap analisa proses bisnis ini juga dilakukan identifikasi peluang-peluang untuk melakukan perbaikan dan perancangan ulang proses bisnis agar proses bisnis lebih efisien. 3. Tahap Perancangan Proses Bisnis Yang Baru Perancangan Proses bisnis yang baru dengan memanfaatkan teknologi informasi dalam menambah nilai proses bisnis perusahaan. Hasil rancangan baru proses bisnis kemudian diimplementasikan dan dilakukan review. Dari tahapan-tahapan rekayasa ulang proses bisnis yang diberikan oleh Whitten, dapat terlihat dengan jelas bahwa kegiatan analisa proses bisnis merupakan bagian dari kegiatan rekayasa ulang proses bisnis. Dalam melakukan analisa proses bisnis, kegiatan dilakukan hingga tahap kedua sedangkan dalam melakukan rekayasa ulang proses bisnis, kegiatan diteruskan hingga tahap ketiga. Pengertian analisa proses bisnis tidaklah dapat dilepaskan dari pengertian rekayasa uang proses bisnis karena analisa proses bisnis merupakan bagian dari rekayasa ulang proses bisnis. Untuk mempunyai gambaran dan pengertian yang lebih baik dan lebih menyeluruh mengenai analisa proses bisnis maka dalam pembahasan berikut ini akan dibahas beberapa pengertian rekayasa ulang proses bisnis. Menurut Whitten (2001, p20) Rekayasa ulang proses bisnis atau business process reengineering (BPR) adalah suatu studi, analisa dan perancangan ulang terhadap proses bisnis yang fundamental untuk menurunkan biaya dan/atau memperbaiki nilai tambah terhadap bisnis. Manganelli (1994, p7) mendefisinikan BPR sebagai perancangan ulang yang cepat dan radikal terhadap strategi, nilai tambah proses bisnis dan - sistem, kebijakan dan struktur organisasi yang mendukung strategic dan nilai tambah proses bisnis - untuk mencapai optimasi arus kerja dan produktivitas dalam suatu 
organisasi. Menurut pengertian Manganelli, dalam melakukan rekayasa ulang bisnis, kita analisa bukan hanya terhadap strategi, nilai tambah proses bisnis tetapi juga terhadap semua sistem, kebijakan dan struktur organisasi yang mendukung proses bisnis yaitu:

1. Sistem yang mendukung kegiatan proses dari proses data dan sistim informasi manajemen hingga ke sistem sosial dan kultural.

2. Kebijakan yang mendukung aktivitas proses biasanya dalam bentuk aturan dan regulasi yang mengarahkan dan memimpin perilaku dalam hal bagaimana suatu pekerjaan dilakukan.

3. Struktur organisasi yang mendukung aktivitas proses adalah kelompok kerja, departemen, area fungsional. divisi, unit dan bentuk lainnya dimana karyawan dibagi untuk kepentingan melakukan pekerjaannya.

Rekayasa ulang proses bisnis merupakan suatu cara yang radikal untuk menggali dan memperluas kemampuan dari suatu bisnis, memperbaiki performancenya dan memungkinkannya untuk mencapai suatu keunggulan kompetitif yang bertahan lama. Studi dan analisa dilakukan terhadap proses bisnis bisa terhadap keseluruhan proses bisnis dalam suatu organisasi atau hanya terhadap suatu proses tertentu dalam organisasi dengan menggunakan metode-metode analisa sistem. Setiap proses bisnis dianalisa dan diteliti secara cermat apakah terjadi bottlenecking, repetisi dan pengerjaan ulang yang mengakibatkan ketidak efisienan. Analisa dan studi ini dimaksudkan untuk menemukan proses bisnis mana yang mempunyai dampak besar terhadap nilai tambah Perusahaan. Terhadap proses bisnis tersebut dilakukan pengkajian lebih lanjut untuk menemukan adanya opportunities yaitu kesempatan untuk melakukan perbaikan sehingga akan memberikan nilai tambah bagi perusahaan. Perbaikan bisa dalam bentuk menghapuskan sebagian proses yang tidak perlu, melakukan streamlining atau memanfaatkan bantuan teknologi informasi. Whitten mengingatkan bahwa dalam melakukan rekayasa ulang bisnis harus dihindari setiap godaan untuk mengfokuskan diri pada solusi informasi teknologi hingga setelah proses bisnis dirancang ulang untuk mencapai efisiensi yang maksimum. Jadi rekayasa ulang bisnis menganalisa proses bisnis dan kemudian Pemodelan Proses Bisnis merancang ulang untuk menghapuskan ketidak efisienan dan birokrasi sebelum di aplikasikan kembali dengan menggunakan teknologi informasi.

\section{Alasan Organisasi Melakukan Analisa Proses Bisnis}

Sebagaimana dijelaskan dalam pengertian analisa proses bisnis dan hubungan antara analisa proses bisnis dengan rekayasa ulang proses bisnis, maka alasan suatu perusahaan dalam melakukan analisa proses bisnis sangatlah tergantung pada alasan Perusahaan melakukan rekayasa ulang proses bisnis yaitu:

1. Untuk memperkuat posisi Perusahaan

2. Untuk mengantisipasi masalah

3. Untuk mengatasi kelemahan Perusahaan

\section{Spesifikasi untuk suksesnya Analisa Proses Bisnis Analisa proses bisnis yang sukses harus mengandung spesifikasi sebagai berikut:}

1. Analisa proses bisnis harus dimulai dengan mengembangkan suatu pernyataan yang jelas mengenai tujuan dan strategi perusahaan.

2. Pertimbangan untuk memberikan kepuasan pada konsumen sebagai tujuan dibelakang tujuan dan strategi perusahaan.

3. Menitik beratkan pada proses bisnis diatas fungsi bisnis dan menselaraskan antara proses dan tujuan perusahaan. 
4. Identifikasikan proses nilai tambah dan proses pendukungnya yang akan memberikan kontribusi terhadap nilai.

5. Menggunakan tehnik dan alat manajemen yang tersedia dan yang sudah proven dengan sebaik-baiknya untuk memastikan kualitas dari informasi yang digunakan dan deliverablesnya.

6. Memberikan analisa terhadap operasi yang sedang berjalan dan mengidentifikasi proses yang tidak memberikan nilai tambah.

7. Mengembangkan terobosan baru bagi suatu kerangka berpikir dan visi yang berani untuk melakukan perubahan yang radikal daripada melakukan perubahan yang bertahap.

8. Mempertimbangkan solusi dimana karyawan dikembangkan dan diperkuat dan teknologi sebagai dasar untuk mengimplementasikan perubahan.

9. Menyajikan suatu masalah bisnis secara lengkap dan memberikan informasi dan argumen yang meyakinkan untuk pengambilan keputusan. 10. Mengembangkan suatu rencana implementasi yang dapat dilakukan yang berisi spesifikasi tugas, sumber daya , jangka waktu dan persetujuan.

\section{Analisa Proses Bisnis Strategis dan Taktis}

Keputusan untuk melakukan analisa proses bisnis dalam rangka melakukan rekayasa ulang proses bisnis bisa merupakan keputusan strategis dan atau keputusan taktis Perusahaan. Kegiatan untuk melakukan analisa proses bisnis dalam rangka rekayasa ulang proses bisnis pada intinya merupakan kegiatan untuk merancang kembali proses yang berada pada area "strategic context". Strategic context dalam hal ini mempunyai tiga komponen kunci yaitu:

1. Kemampuan yang distinctive dari suatu bisnis

2. Segmen atau pasar untuk bisnis tersebut

3. Keunggulan kompetitifnya yang bertahan lama. Kemampuan yang distinctive dari suatu bisnis bila diaplikasikan pada segmen dan pasarnya akan memberikan keunggulan kompetitif bagi bisnis tersebut untuk bertahan terus dalam persaingan dan bertahan dalam eksistensinya.

Bertolak dari ketiga komponen strategic context tersebut, ada empat pertanyaan penting yang perlu dipikirkan lebih dalam yaitu:

1. Apa yang merupakan kemampuan yang kita miliki yang bersifat distinctive dimata pelanggan kita?

2. Apakah kemampuan tersebut telah diaplikasikan dalam pasar kita?

3. Apa kemampuan baru yang perlu kita kembangkan lebih lanjut agar posisi keunggulan kompetitif kita pada pasar dapat lebih kuat?

4. Apa yang perlu dilakukan untuk memperbaiki kemampuan kita sekarang agar memperkuat keunggulan kompetitif kita?

Analisa proses bisnis dalam rangka rekayasa ulang bisnis pada intinya adalah bertujuan dan berlandaskan pada konsep untuk memberikan nilai tambah kepada pelanggan kita lebih dari apa yang dapat diberikan oleh pesaing melalui suatu perbaikan yang radikal terhadap kemampuan yang telah kita miliki dan menciptakan kemampuan baru yang bersifat distinctive. Analisa Proses Bisnis - Strategis Analisa proses bisnis dalam rangka rekayasa ulang proses bisnis yang bersifat strategis mempunyai ruang lingkup pembahasan yang berbeda dengan yang bersifat taktis.

Analisa proses bisnis dalam rangka rekayasa ulang proses bisnis strategis atau disebut juga strategic analysis and reengineering biasanya mempunyai skala besar dan bersifat jangka panjang dimana secara mendasar melakukan transformasi cara organisasi melakukan bisnis 
yang akan berdampak pada strategi bisnis secara keseluruhan. Analisa proses bisnis dalam rangka rekayasa ulang proses bisnis yang bersifat taktis atau disebut juga analisa dan rekayasa ulang operasional bersifat lebih praktis dan dengan cara yang cepat namun tetap harus mendukung terhadap strategi bisnis.

Analisa proses bisnis operasional lebih sederhana dan praktis yang mana dapat dilakukan oleh manajer pada semua tingkatan.

Situasi strategi bisnis sangat ditentukan oleh interaksi antara lingkungan, stakeholder, pesaing , pelanggan dan pemasok. Situasi operasional bisnis sangat ditentukan oleh interaksi antara orang yang ada dalam organisasi, pekerjaan- pekerjaan, infrastuktur yang ada serta sistem dan prosedur.

Strategi bisnis menentukan bagaimana operasional harus dijalankan untuk mencapai hasil yang telah ditetapkan. Operasional sangat menentukan apa yang menjadi hasil yang diharapkan yang dapat mendukung pelaksanaan strategi bisnis.

Analisa dalam rangka rekayasa ulang strategis dimulai dengan menentukan apa yang ingin dicapai (strategi) sebelum menentukan bagaimana mencapainya (operasional).

Pendekatan yang dilakukan adalah bersifat Top - Down atau dari atas ke bawah baik secara konseptual maupun secara managerial dengan starting pointnya berupa situasi strategis.

\section{Langkah-langkah penting dalam melakukan analisa proses bisnis strategis:}

1. Identifikasi proses inti operasional dan managerial dengan hasil suatu map proses tingkat tinggi (high level process map)

2. Proses ini dievaluasi dalam hal dampaknya terhadap pelanggan, tingkat kesuksesannya dan feasible atau tidaknya bila dilakukan perancangan ulang dalam suatu jangka waktu tertentu.

3. Mengembangkan suatu visi bagaimana suatu organisasi beroperasi dimasa yang akan datang serta menentukan satu atau dua proses inti lainnya yang mendapat prioritas untuk dilakukannya perancangan ulang. Hasil dari analisa proses bisnis strategis mengidentifikasikan peluang-peluang untuk memperbaiki dan melakukan perancangan ulang proses bisnis, yang merupakan dasar bagi Perusahaan dalam penetapan skala prioritas. Hasil analisa ini juga merupakan dasar bagi Perusahaan untuk melakukan perancangan ulang proses bisnis yang kemudian dituangkan dalam suatu peta atau high level process map yang merupakan blue print perusahaan dalam rangka mencapai strategi jangka panjang Perusahaan

\section{Analisa Proses Bisnis - Taktis}

Analisa proses bisnis yang bersifat taktis dilakukan pada tingkat operasional Perusahaan yang lebih terfokus pada masalah masalah konkrit dan riil seperti creative organization redesign dan change management, tidak terfokus pada hal yang abstrak seperti strategi, sifat bisnis dan proses inti.

\section{Faktor kritis untuk suksesnya analisa proses bisnis yang bersifat taktis adalah:}

1. Mengetahui secara jelas situasi bisnis dimana suatu organisasi berada dan masalah yang dihadapi

2. Apa yang bisa menambah nilai pada bisnis

3. Apa yang mempengaruhi hirarki manajemen

4. Bagaimana melakukan diagnosa terhadap bisnis operasi kita

5. Bagaimana menggunakan teknik dan peralatan yang sangat esensial

6. Bagaimana secara sukses dapat memanage perubahan. 


\section{Daftar Pustaka}

1. Rangkuti, F(2007). Busines Plan.Teknik membuat Perencanaan Bisnis dan Analisis Kasus, Jakarta: PT Gramedia.

2. Vincent, G(1997). Statistical Process Control:Penerapan Teknik-Teknik Statistikal Dalam Manajemen Bisnis Total ,Jakarta: PT Gramedia

3. Yefta, SK(2007).Analisis Proses Bisnis unutk Dinas Pemerintahan: Mendapatkan Proses Bisnis As-ls Hingga Rancangan Proses Bisnis To-Be, dalam Wibowo, T.A(Ed), Berbagai Makalah Sisitem Informasi, Prosiding Konferensi Nasional Sistem Informasi 2007, Bandung: Departemen Teknik Informatika, Sekolah Tinggi Teknologi Telkom, 25-30.

4. Surjadi, K(2007).Identifikasi Indikator keberhasilan Kinerja Perusahaan Berbasis Proses Bisnis Sebagai dasar Penentuan Kebutuhan Informasi, dalam Wibowo, T.A(Ed), Berbagai Makalah Sisitem Informasi, Prosiding Konferensi Nasional Sistem Informasi 2007, Bandung: Departemen Teknik Informatika, Sekolah Tinggi Teknologi Telkom, 47-58.

5. Solikin (2007).Model Audit Sistem Informasi di Perguruan Tinggi Menggunakan Kerangka Kerja CobiT, dalam Wibowo, T.A(Ed), Berbagai Makalah Sisitem Informasi, Prosiding Konferensi Nasional Sistem Informasi 2007, Bandung: Departemen Teknik Informatika, Sekolah Tinggi Teknologi Telkom, 85-90.

6. Wibawa, IGA(2007).Pedoman Analisis Proses Bisnis, dalam Wibowo, T.A(Ed), Berbagai Makalah Sisitem Informasi, Prosiding Konferensi Nasional Sistem Informasi 2007, Bandung: Departemen Teknik Informatika, Sekolah Tinggi Teknologi Telkom, 109-112.

7. Suryani, AA.,Wijoyo MH.,Partasubita SW(2007).Pengembangan Model Information Technology (IT) Governance pada organisasi Perguruan Tinggi, dalam Wibowo, T.A(Ed), Berbagai Makalah Sisitem Informasi, Prosiding Konferensi Nasional Sistem Informasi 2007, Bandung: Departemen Teknik Informatika, Sekolah Tinggi Teknologi Telkom, 139-146 